\title{
Preserving human resource of Vietnamese enterprise in covid-19 pandemic
}

\author{
Anh Phuong Tran and Thuy Le Duc \\ Faculty of Business Management \\ Hanoi University of Industry \\ Hanoi, Vietnam \\ phuongta@haui.edu.vn
}

\begin{abstract}
The impact of the Covid-19 pandemic is still a heavy consequence and forces businesses to respond promptly to ensure their production process. Labor supply disruption is occurring in some localities. Enterprises need to have a plan to bring workers, who have been severely impacted by the pandemic both physically and mentally, back to production activities safely. The study focuses on the perceptions of business leaders about responding to the impacts of Covid-19 on the enterprise's human resource management and efforts to preserve the enterprise's human resources. The research is based on information and data from a survey and direct interviews from senior managers of 50 manufacturing enterprises in different fields in some industrial zones in northern Vietnam.
\end{abstract}

Index Terms - Covid-19 pandemic, protecting HR, industrial zone, Human resource management, safet factors.

\section{INTRODUCTION}

$\mathrm{T}$ HE COVID-19 pandemic is being considered as one of the catastrophes of humans. It claimed the lives of millions of people around the world, and also delayed the world's economic development for decades. Vietnam has been affected by the pandemic since January 2020. After two years, the severe effects of this pandemic are clearly felt in every aspect of the economy. The prolonged periods of social distancing in many provinces and cities in the past time to prevent and control the Covid-19 epidemic have greatly affected the labor market.

During a pandemic, due to the implementation of social distancing measures, goods circulation will be disrupted, production and business will be delayed. Many enterprises are forced to choose the " 3 on-site" or "1 route, 2 destinations" production option to be able to continue their production and business activities. However, in order to implement the above options, enterprises face many difficulties such as higher production costs, affected human resources, and disruption of input materials. This is especially important for exporters, who can hardly complete the production and deliver the goods on time, so they have to renew or cancel the contract signed with their partner. Many businesses went bankrupt or dissolved due to exhaustion and could no longer endure the epidemic for a long time. In addition, many other businesses also had to temporarily suspend business, do business in moderation, produce inefficiently, or make losses in the context of the epidemic. From the beginning of 2021 until now, nearly 13 million people of working age in the country have been affected in terms of employment and income. In particular, from the end of June to the beginning of August, localities recorded that nearly $10 \%$ of units and businesses had to suspend production and business, equivalent to nearly 4 million workers who had to temporarily stop working. Along with businesses, one of the subjects heavily affected by this pandemic is the employees of the enterprise in particular and the human resources of the country in general $[2,4,15]$.

\section{Impact of Covid-19 Pandemic and Some Basic Concepts of "Preserving Human Resources"}

According to Venkatesh [1, page 1] "the individual's knowledge, experiences, capabilities, skills, creativity and innovativeness. These elements are connected to each other and collectively contribute to success in work".

In a narrow sense, human resource is the labor capacity of society, a resource for socio-economic development, including the working-age population, capable of participating in labor, Social production, i.e. all specific individuals participating in the labor process, is the sum total of their physical, mental and spiritual factors mobilized in the labor process.

Human resources are expressed in two ways: (1) In terms of quantity, it is the total number of people in the organisation and the working time that organisation can be mobilized from them; (2) In terms of quality, it is the health, knowledge, skills and attitude of workers in the organization.

With the above understanding, conservation of human resources is understood as the stabilization of the number of employees as well as the quality of human resources to serve the production and business activities of enterprises during and after the pandemic.

According to labor experts, the epidemic and prolonged social distancing have forced workers to find other jobs to do, or leave industrial zones to return to their hometowns, causing businesses to experience labor shortages after the pandemic. when the Covid-19 epidemic became serious. It is expected that the number of workers returning home to return to work is only about $60-70 \%$, which will create a big paradox in terms of labor supply and demand. Finding ways to ensure that there is no shortage of labor resources for production and business activities is considered a difficult problem for businesses today.

\section{Research Methodology}

Our research is based on the survey of 50 managers of manufacturing enterprises in the industrial zones. We conducted the survey from May to July 2021 in some northern 
industrial zones like VSIP (Bac Ninh province), Dong Van (Ha Nam province), Song Khe - Noi Hoang (Bac Giang province), and Quang Minh (Hanoi). The detailed information is presented in table 1 .

Table 1: Information of research sample

\begin{tabular}{|c|c|c|c|c|}
\hline Order & Criteria & Classification & Number & $\%$ \\
\hline \multirow[t]{2}{*}{1} & \multirow[t]{2}{*}{ Sex } & Male & 42 & $84 \%$ \\
\hline & & Female & 08 & $16 \%$ \\
\hline \multirow[t]{3}{*}{2} & \multirow[t]{3}{*}{ Age } & Under 30 & 6 & $12 \%$ \\
\hline & & $30-45$ & 29 & $58 \%$ \\
\hline & & More 45 & 15 & $30 \%$ \\
\hline \multirow[t]{3}{*}{3} & \multirow[t]{3}{*}{ Formation } & Bachelor & 35 & $70 \%$ \\
\hline & & Master & 13 & $26 \%$ \\
\hline & & $\mathrm{PhD}$ & 2 & $4 \%$ \\
\hline \multirow[t]{3}{*}{4} & \multirow{3}{*}{$\begin{array}{l}\text { Experienc } \\
\mathrm{e}\end{array}$} & Under 3 years & 6 & $12 \%$ \\
\hline & & $3-10$ years & 25 & $50 \%$ \\
\hline & & More 10 years & 19 & $38 \%$ \\
\hline \multirow[t]{5}{*}{5} & \multirow[t]{5}{*}{$\begin{array}{l}\text { Type of } \\
\text { enterprises }\end{array}$} & $\begin{array}{l}\text { Electrical } \\
\text { equipment }\end{array}$ & 14 & $28 \%$ \\
\hline & & Garment & 12 & $24 \%$ \\
\hline & & Wood and papers & 8 & $16 \%$ \\
\hline & & Plastic products & 6 & $12 \%$ \\
\hline & & Others & 10 & $20 \%$ \\
\hline \multirow[t]{4}{*}{6} & \multirow[t]{4}{*}{$\begin{array}{l}\text { Industrial } \\
\text { zones }\end{array}$} & $\begin{array}{ll}\text { Quang } & \text { Minh } \\
\text { (Hanoi) } & \\
\end{array}$ & 18 & $36 \%$ \\
\hline & & VSIP (Bac Ninh) & 12 & $24 \%$ \\
\hline & & $\begin{array}{l}\text { Song Khe }- \text { Noi } \\
\text { Hoang } \\
\text { Giang) }\end{array}$ & 12 & $24 \%$ \\
\hline & & $\begin{array}{lll}\text { Dong } & \text { Van } \\
\text { Nam) } & & \\
\end{array}$ & 8 & $16 \%$ \\
\hline
\end{tabular}

Research focuses on the problem of Human Resource Management of manufacturing enterprises. The research questions were divided in three main parts:

- Awareness of impact of Covid-19 pandemic

- Perception of managers about the impact of Covid-19 pandemic on their enterprises

- Stabilization of Human Resource after covid-19 pandemic

\section{PERCEPTION OF BUSINESS LEADERS ABOUT RESPONDING TO THE IMPACT OF THE COVID-19 PANDEMIC ON HUMAN RESOURCE MANAGEMENT ACTIVITIES OF ENTERPRISES.}

The Covid pandemic has clearly changed the previous human resource management methods. The perception of the need to change to cope with the actual situation has shown the agility of business leaders in the process of managing human resources during the crisis. According to the survey, most leaders realize the necessity of a number of issues: (1) Cost management and balancing human resource management activities; (2) Urgency in applying and stabilizing new working methods; (3) Immediate implementation of safety measures for workers to prepare to return to operation.

4.1 Awareness in managing costs and balancing to human resource management activities
During the 2 years of the pandemic, the production and business situation was continuously stalled because of the epidemic and the shortage of raw materials and workers caused most businesses to struggle and seriously reduce their revenue and the profit. This situation will continue in the near future. According to the report of VCCI, "The impact of the Covid-19 epidemic on Vietnamese businesses", the survey results show that 2020 is a difficult year when up to $87.2 \%$ of businesses are affected at "mostly" or "totally negative" due to the Covid-19 epidemic, only $11 \%$ of businesses said that they were "unaffected at all" and nearly $2 \%$ recorded an "totally positive" or "completely positive" impact "mostly positive". Many sectors have been significantly impacted by the covid19 pandemic. Specifically, industries such as garment industry (97\%), information and communication industry 96\%, electrical equipment manufacturing industry $94 \%$. For foreign direct investment (FDI) enterprises in Vietnam, the level of impact is as follows: $100 \%$ for real estate enterprises; $97 \%$ for communication enterprises; $95 \%$ for agriculture, fishery enterprises. Notably, those most negatively affected are new businesses operating under 3 years and micro and small scale enterprises. Particularly in Hanoi, according to the report of Hanoi Department of Planning and Investment, in August 2021, the unit carried out dissolution procedures for 244 enterprises; 833 businesses registered to suspend operations mainly due to difficulties caused by Covid-19 [2,3].

This forces business owners to consider applying the strictest and most effective capital control process. The capital control directly affects other management activities including human resources. This is probably the time when business leaders and managers have to deal with the problem of balancing human resources, both limiting labor cuts and assigning jobs in accordance with current human resources. According to the 2020 survey of businesses of VCCI, 35\% of private enterprises and $22 \%$ of FDI enterprises have had to lay off their employees due to the impact of the epidemic. The general estimate shows that the number of employees who have to be laid off accounts for about $30 \%$ of the total number of employees in an enterprise. Facing the consequences of the Covid-19 pandemic, some businesses were forced to make decisions to cut staff and cut wages and benefits.

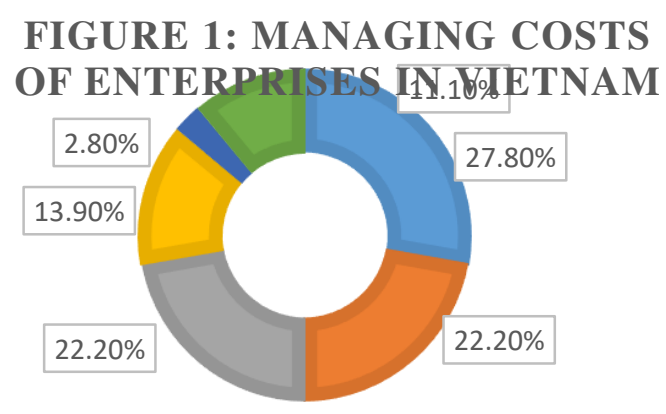

From 10 to 50 employees

(Source: Navigos)

According to statistics of Navigos (Vietnam's leading human resource group) for 1,400 enterprises in Vietnam, 
$27.8 \%$ of enterprises with about $10-50$ people have made this decision. At the same time, both enterprises with sizes from 51-100 and 101-300 are accounting for the same proportion of $22.2 \%$. Most importantly, even with a large-scale operation, it is inevitable to reduce human resources. With a scale greater than 1000 , about $11.1 \%$ of businesses are optimizing and tightening operating costs. In addition, multinational corporations, companies that mainly deal with foreign partners also face restrictions on movement, which negatively affects work efficiency [5,6].

4.2 Awareness of the urgency to adopt and settle into new ways of working.

In the new situation, when the epidemic has not ended and the global supply chain has not fully recovered, businesses will certainly have changes due to low or slow operational demand. The application and change of working methods, prominently the trend of working from home (WFH) is inevitable. Changing working methods will make a surplus of labor and therefore, the risk of having to reduce personnel is certain to occur, especially in commercial and service enterprises. Leaders of enterprises must be aware of the need to accelerate the automation process and apply new working methods in production and business activities.

When operating under a new working method, a human resource department will not have enough skills and technology to ensure work efficiency. It requires administrators to anticipate reduced work performance due to the lack of ability to work remotely and have timely response solutions. WFH has three core things to care about: infrastructure, corporate culture and data security. Some questions must be answered correctly like: Will customer service be affected? Are workers of different generations happy? Can the management and infrastructure meet the above? Which target group is needed first? (because not all professions can WFH effectively, such as bank teller, service...).

According to Ms. Thanh Le (office director of Adecco City, HCMC), to ensure efficiency in WFH, companies must invest in upgrading facilities such as intranets (VPNs), servers, cloud data storage, buy new technical equipment, buy software, support tools when working remotely...

From the perspective of a domestic business owner, Mr. Nguyen Si Trieu Chau (founder of Atoha Institute of Project Management) said that if the Millennial generation (born from 1981-1996) accumulated enough knowledge, most of the careers are stable or mature, so they have enough endurance to react appropriately to the "post-COVID" era, the story is very different from Gen Z. "Growing up in the technology age, so the personality and worldview are more affected by technology, less patient and difficult to concentrate than previous generations. During the pandemic, due to the implementation of epidemic prevention measures, young people often experience problems with higher levels of loneliness and depression than older people. Therefore, helping young people improve their own capacity to better adapt to a new working environment like WFH plays an important role $[8,9,11]$.
Ms. Nguyen Thanh Huong (national human resource director of ManpowerGroup Vietnam) said that: In addition to providing flexible working policies, businesses should support training for employees in new ways of working. use digitization tools, arrange time, manage work... As for the leaders, they need to put in place a lean but effective management mechanism with a "digitized" mindset. Sharing and empathy is also something that employees always need at the management level during the WFH period, when daily communication and "hands-on" no longer exist. Mechanisms for monitoring and managing work should be clearer.

4.3 Awareness of the implementation of safety measures immediately for workers to prepare returning operations.

Returning to operation is inevitable. Business leaders have become seriously aware of the problem of changing requirements and measures to ensure workplace safety such as wearing masks, testing for employees, etc. face the process of reorganizing work positions to ensure distance. Implementation of the program "business green zone", "shifting, channeling"... are compulsory activities for enterprises. Although these activities cause a lot of costs for businesses.

\section{ENTERPRISES' EFFORTS TO STABILIZE HUMAN RESOURCES AFTER THE PANDEMIC.}

Before returning to operation, most enterprises focus on the questions: "How to ensure the safety and health of employees?", "We should arrange and set a schedule for the increase. How is the production speed?", "Will employees be assured to return to work? Can businesses reopen?", "What conditions will facilities in different countries, cities or locations have to pay attention to?", "How to maximize revenue in the short term?" during the COVID-19 period?", "What are the costs of getting employees back to work?". This will be even more complicated for organizations with multiple businesses and regulations. On an international scale, COVID19 may affect businesses to varying degrees, and return to work times will vary significantly from region to region. Therefore, to answer the above questions, according to the research team's survey, most businesses consider decisions about returning to work based on 4 criteria: (1) Health \& safety of employees, (2) Classification of types of work, (3) Financial situation of the enterprise, (4) Needs and aspirations of employees.

\subsection{Health \& safety of workers}

Businesses need to consider whether they have ensured compliance with Government directives and health, safety and environment (HSE) regulations. Businesses are only allowed to operate when they meet the minimum requirements set by the state. The HR department should ensure a safe and hygienic work environment, establish rules for the shared use of equipment and workspaces, and consider appropriate medical practices as part of the re-opening process (Example: temperature check)... Businesses always need to be ready to check the environment, health, safety and emergency response to comply with regulations. "3 on-site" model (which involves eating, sleeping, and working without leaving aims to keep production going while ensuring COVID-19 control) is 
considered an initiative during the epidemic season. According to the ILO summary, many factories of enterprises are built solely for production purposes and are not suitable environments for employees to stay under the " 3 on-site" model. Enterprises need an assessment to ensure safety factors when allowing a large number of workers to stay in the factory. The fact that many workers stay in the factory for a long time can increase occupational safety and health risks in the workplace. The re-evaluation of these risks is very necessary and requires the participation of workers as well as trade union representatives to quickly implement remedial and preventive measures.

Businesses need to ensure compliance with Government directives on health, safety and environment (HSE) in activities such as: Monitoring and ensuring compliance with Government directives on HSE; Consider working with foreign or outsourced suppliers and global service providers, as many closures will affect business continuity; Understand and balance the need to protect personal data when performing due diligence activities to collect, use and share data to identify, reduce risks, and protect a safe work environment against direct risks.

At the same time, it is necessary to build a safe working environment through the following activities: Update policies and regulations on health and safety; Consider more stringent workplace hygiene practices; Consider reorganizing the workplace (e.g. retrofitting screens to limit close contact between employees); Disseminate social distancing guidelines on a regular basis; Establish a mechanism to control the movement of workers; Liaise with trade unions to adjust work regulations to ensure social distancing; Consider adjusting working hours to limit concentration in peak hours; Consider the mental health of employees, be aware of the impact and fear that the epidemic causes.

The basic requirement is that businesses need to comply with health regulations in order to establish a proper Return to Operation process. Check the use of personal protective equipment against the HSE guidelines; Review health checks (e.g., temperature measurement, questionnaire health) and balance them with other privacy policies and rights; Consider adding medical staff in the workplace or training first aid personnel to assist with medical problems; Develop a process of checking and screening visitors to work; strict human resource management; Know exactly where they are going in and out of the workplace, keeping track of where they've been before.

Businesses also need to review their health, safety and environmental and emergency response procedures to be consistent with HSE regulations. Prepare a process to quickly respond to new infections or outbreaks, including communication channels, plans to close the workplace/office, etc. Establish a plan to identify and monitor employees, relatives of employees suspected of being infected; Consider leveraging mobile tracking technologies.

For example, ABB Power Grids Vietnam Co., Ltd. has more than 700 officers and employees. During the period of isolation, the company implemented the "business green zone" model under the guidance of the government and the Covid task force focused on solving health and safety issues for employees during the epidemic season. Covid-19 safety teams all have situation reports, if anyone is found with epidemiological factors, the company will provide test strips. With this model, there are currently 60 people working " 3 on the spot"; $100 \%$ of workers are tested weekly; $95 \%$ of employees get 1 st dose vaccine and $5 \%$ get 2 nd dose vaccine. Along with that, the company removed the regulation on handover between 2 direct shifts. The working shifts do not meet, the first shift is finished, the next shift is new; Locations that can eat on the spot will receive lunch boxes, not concentrated meals. At ICHI Vietnam Company, the company implements "1 route 2 destinations", all employees must register the route and commit to do it correctly. With lunch, the company divides boxes of employees' positions to ensure distance.

5.2 Classification of types of work

In order to have a reasonable and effective reduction or transfer of personnel as well as effective change of remote working methods, the human resources departments of enterprises need to identify the main and mandatory services according to the contract. community and related roles; Identify locations where it is necessary to interact with others (at work or outside) or to share equipment and technology; Be aware of potentially hazardous jobs and compliance issues if work is not done in the workplace; Evaluate jobs that can significantly reduce productivity if working outside.

Businesses need to identify locations that require direct contact with others (onsite or offsite). Consider and evaluate how these activities will change with the new way of working; Is it necessary to have too much direct contact with customers? (Example: Head of Sales, Customer Relations). For positions where telecommuting is possible, consider a reasonable allocation of office and home time, e.g. possibly rotating weekly or shift work at the office.

At the same time, identify positions that require direct interaction with machines and technology. Evaluate jobs that will not be effective without technology or machines that are permanently located in the workplace. For jobs that must be performed in a workplace such as a manufacturing plant, consider arranging fixed shifts, or adjusting working hours to limit exposure.

Enterprises need to understand the work that is prone to risks and the issues to be followed if the work is not done on site. Identify risks, assess risk monitoring, and improve compliance when work is done on-site (e.g. trading operations). Assess data security/cybersecurity risks when working remotely or over a VPN network. Evaluate jobs and positions that will not be affected when working remotely, thereby planning future work arrangements with full technology support and resources.

Identify jobs and positions that have reduced productivity when working remotely. Evaluate the effectiveness of each position when working remotely during a crisis. This can be influenced by many different factors such as function, role, personal circumstances, technology. From there, understand 
which jobs are effective and which are reduced when working remotely.

\subsection{Financial situation of the enterprise}

Understanding the costs incurred and the savings when employees return to work (eg, costs of security, hygiene, labor protection) is really necessary in the perception of businesses. In difficult times, only strong finance can help businesses get through the pandemic. According to statistics, it is difficult for SMEs with limited capital to overcome the pandemic. Simultaneously with cost savings, businesses need to identify and maintain new revenue streams or expand existing services (e.g. new products/services). In particular, it is necessary to plan for changes in business-specific needs during the recovery period.

Businesses need to understand the costs incurred or saved when bringing employees back to work (e.g. security fees, cleaning fees). Consider the costs involved in bringing employees back to work after the pandemic. For example: Regularly cleaning, disinfecting, disinfecting o Using personal protective equipment; Increase training in workplace health and safety; Reorganize working position (office, factory, workplace); Expenses for the implementation of medical measures; Meals and allowances; Determine the savings if you continue to work remotely. Example: Direct training costs; Facilities, food costs, workplace security, cleaning costs; Office services...

Identify and maintain new revenue streams or expand existing offerings (e.g. new products/services). Find and seize revenue generation opportunities in the post-pandemic context, such as expanding factories to develop essential products and services, creating new services, and more. Consider changing business strategies appropriately in the context of new realities, ranging from changes in employee working needs, customer habits to post-COVID-19 outsourcing options (e.g. business models). business / service model will become more basic, simpler than before the pandemic).

Plan for changes in business-specific needs during the recovery period: Scenarios for an increase or decrease in market demand as society gradually returns to normal; Understand more about your business' financial and operational issues after the upheaval (e.g., post-pandemic, restaurants can only operate at $50 \%$ capacity) $[12,16,17]$

5.4 Needs and aspirations of employees

Workers are suffering heavily from the pandemic when they are directly hit with wages and health. In order for employees to be mentally stable and ready to return to the system, enterprises need to assess workers' attitudes on health and safety and hygiene issues in the current situation and grasp personal circumstances. employees (eg, childcare, financial situation) and affect work performance. During the work-from-home, teleworking phase, HR also needs to assess the reliance of teleworking and consider the effectiveness of support tools. The survey process of enterprises will help businesses have clear orientations and solutions for their human resource management activities.
Businesses need to assess employees' attitudes towards their health and hygiene in the current context. Consider employees who need to stay home for extended or indefinite periods (the implications of this); Be aware of the impact on employee safety. Understand and address their anxiety and insecurities, and promote activities that support mental health; Know the location of employees and the means of transport they use, thereby assessing their exposure during daily travel; Assess the need between business travel and online meetings; Monitor and develop employee feedback channels to understand employees' opinions and feelings during the postpandemic recovery period and take reasonable actions to address employee concerns, as well as encouraging their successes in times of crisis. Also according to the ILO's summary report, the psychological health of employees is one of the important issues businesses need to pay attention to. The process of working under the closed " 3 on-site" model will be able to adversely affect the psychology of employees, cause distraction in the working process and affect the safety of workers. Taking care of the quality of meals and after-hours entertainment are good practices shared by businesses to create a more comfortable environment for employees during "3 on-site" implementation.

Businesses need to understand personal circumstances (e.g. childcare, financial problems). Working at "3 on-site" enterprises is often quite difficult for employees who are obliged to take care of their families. Enterprises need to prepare to support employees to keep in regular contact with their families as well as arrange support in other necessary cases when employees are absent from their families. Understanding an individual's circumstances, as well as understanding how social situations will affect their decision to return to work (e.g., if schools continue to be closed, employees may find it difficult to return to work). back to work because there is no one to look after the children). Consider how financial matters affect an employee's decision to return to work. Know your employees' needs and aspirations about each working method, understand their concerns from their perspective - for example, they may feel isolated when working remotely, or they may worry about anxiety and stress when returning to the workplace.

Finally, we need to evaluate the effectiveness of remote working through new tools and working methods. Therefore, businesses must prioritize investing in tools and platforms to continue to increase efficiency when working remotely such as collaboration software, network bandwidth, laptops, WiFi or VPN access (Virtual Private Network), managed access and security on the network. Businesses need to regularly evaluate whether working online is effective and maintain employee engagement to any degree.

\section{CONCLUSION}

The issue of human protection should lead with policies and fast and empathetic communication through activities that maintain two-way communication channels to capture the opinions of the workforce; Manage workforce data to ensure accurate employee tracking; Implement policies to protect and 
support employees and ensure compliance with Government guidelines and regulations; Promote respect and inclusion, support employee health; Improve or establish employee benefits and support programs...

Ensure work safety and efficiency when implementing new ways of working and new forms of connection. HR needs to determine the effectiveness of a telework program; Develop and build solid telecommuting capabilities (for both employees and leaders); Measuring workforce productivity and engagement; Align HR program priorities (e.g. planning for key roles, performance and compensation evaluation, talent management); Promoting new ways of working through enhanced digitalization; Measure the effectiveness of the customer experience; Lead and connect with the workforce in different ways to inspire change and uncertainty.

Businesses need to evaluate short- and long-term labor cost measures to plan for sustainability. Assess roles and functions (compare supply and demand) and redeployment possibilities; Identify and calculate pre-reduction measures (e.g. employee benefits, insurance, shortening of work hours, temporary layoffs, division of labor or part-time work); Analyze the consequences associated with each of these short-term measures compared to using the Government's COVID-19 support package; Identify possible redeployment of workers to meet increased demand and secure key functions; Connecting and inspiring the workforce is retained to focus on the vision for the future beyond the crisis.

Prepare for increasing demand through strategic HR planning with HR strategy refreshes including organizational structure design; Identify aspects of post-crisis working practices; Continuing momentum across technology platforms by investing in specific skills and competencies; Maintain and establish access to key and critical human resources.

\section{REFERENCES}

[1] Venkatesh Ganapathy, Strategic Management of human captital, NXB Bookboon, 2018.

[2] Tổng cục thống kê (2021), "Tác động của dịch Covid-19 đến tăng trưởng các khu vực kinh tế quý III năm 2021”, https://www.gso.gov.vn/du-lieu-va-so-lieu-thong-ke/2021/10/tacdong-cua-dich-covid-19-den-tang-truong-cac-khu-vuc-kinh-te-quy-iiinam-2021/

[3] VCCI, "Survey Report on the Impacts of Covid-19 on Business Performance", Published on 5 May 2020.

[4] ILO, "Tác động của đại dịch COVID-19 tới doanh nghiệp và người lao động trong một số ngành kinh tế chính: Úng phó, điều chỉnh và khả năng phục hồi", 2020).

[5] Navigos, "Thị trường lao đọng trong làn sóng Covid-19 thứ 4", 2021.

[6] Đại học Kinh tế Quốc dân (2020), Báo cáo đánh giá tác động của Covid-19 đến nền kinh tế và các khuyến nghị chính sách

[7] GSO, Report on impact of covid-19 pandemic on labour and employment of the second quarter of 2021, (2021)

[8] World Health Organization, The WHO Special Initiative for Mental Health (2019-2023): Universal Health Coverage for Mental Health. World Health Organization. Geneva, 2019.

[9] Brook S.K., Webster R.K., Smith L.E., Woodland L., Wessely S., and Greenberg, N. "The Psychological Impact of Quarantine and How to Reduce it: Rapid Review of the Evidence". Lancet, 395, 2020.

[10] Worldometers, "Covid-19 Coronavirus Pandemic", 2021.

[11] Xiong J., Lipsitz O., Nasri F., Lui, L., Gill, H., Phan, L., Chen-li, D., Iacobucci, M., Ho, R., Majeed A. and McIntyre, R. "Impact of COVID-19 Pandemic on Mental Health in the General Population: A Systematic Review”. Journal of Affect Disorder, 277, page 55-64, 2020.

[12] Nguyễn Bích Lâm, "Đại dịch COVID-19, hệ lụy và giải pháp hỗ trợ doanh nghiệp", Báo điện tử Chính phủ, 2020.

[13] Shrestha, N. et al, The Impact of COVID-19 on Globalization, One Health, 2020.

[14] The World bank, Ngân hàng Thế giới tại Việt Nam, 2021.

[15] Tổng cục thống kê, Báo cáo tác động của dịch COVID-19 đến tình hình lao động, việc làm quý IV và năm 2020, 2021.

[16] Everland News, Ẩnh hưởng của dịch COVID-19 đối với kinh tế Việt Nam dưới góc nhìn chuyên gia, 2021.

[17] Song, L. and Zhou, Y., "COVID-19 Pandemic and Its Impact on the Global Economy: What Does It Take to Turn Crisis into Opportunity? China World Economy, Vol.28, No.4, 2020. 